\title{
Statusul nutrițional matern, o condiție sine qua non pentru evoluția fătului, nou-nằscutului, copilului și adultului
}

\author{
Cosmin Rugină' ${ }^{1}$ Cristina Oana Mărginean², Lorena Elena Meliț².Claudiu Mărginean' ${ }^{1}$ \\ ${ }^{1}$ Departamentul Obstetrică-Ginecologie, Universitatea de Medicină, Farmacie, Științe și \\ Tehnologie „George Emil Palade", Târgu Mureș, România \\ ${ }^{2}$ Departamentul Pediatrie I, Universitatea de Medicină, Farmacie, Științe și Tehnologie \\ "George Emil Palade“, Târgu Mureș, România
}

\begin{abstract}
REZUMAT
Câştigul ponderal excesiv al femeii gravide este un factor predictiv pentru obezitatea maternă, cu implicații asupra greutății nou-născuților și posibile complicații pe termen scurt și lung. Câştigul ponderal în sarcină depinde de factori etnici, sociali şi de paritate. Exceptând factorii menționați anterior, nu este de neglijat nici impactul major al susceptibilității genetice, punându-se în evidență că există trei perioade principale ce influenţează evoluţia fetală, și anume periconcepţională, intrauterină şi postnatală. Mediul intrauterin deține un rol esenţial în dezvoltarea optimă a fătului, având efect asupra structurilor şi funcţiilor organelor produsului de concepţie, considerându-se în acest moment că bolile adultului îşi au originea în copilărie. Astfel, este bine cunoscută legătura dintre câștigul ponderal gestațional excesiv și obezitatea sau bolile metabolice la copil. Mai mult, unele dintre cele mai noi informații din literatură sugerează că alergiile, wheezing-ul sau astmul copilului ar putea avea, la rândul lor, legătură cu statusul nutrițional matern.

În concluzie, excesul ponderal gestațional deține un rol decisiv în apariţia obezităţii şi bolilor metabolice la copil, de aici rezultând importanţa majoră a unei diete echilibrate pe perioada sarcinii pentru a favoriza un câștig ponderal optim, cu efect pozitiv asupra bunăstării fetale, care să prevină riscul metabolic al produsului de concepţie.
\end{abstract}

Cuvinte cheie: câștig ponderal în sarcină, obezitate maternă, greutatea nou-născutului

\section{INTRODUCERE}

Obezitatea reprezintă o problemă importantă de sănătate publică, un flagel al secolului XXI, cu multiple implicații pe termen scurt și lung. Câştigul ponderal gestaţional excesiv este un factor predictiv pentru obezitatea maternă postpartum ce are implicații asupra greutății feților (posibilă macrosomie fetală) și a greutății la naștere a nou-născuților, cu implicații pe termen scurt și mediu ca obezitate în copilărie şi paralizie cerebrală sau pe termen lung, precum atac vascular cerebral, boală coronariană, obezitate, diabet zaharat tip 2 şi astm (1). Rooney şi colab. au dovedit că factorii predictivi pentru obezitate la femeia gravidă includ câştig ponderal prea mare în timpul sarcinii şi incapacitatea acestei de a-şi reduce greutatea câștigată în sarcină după 6 luni de la naştere (2).
Institutul de Medicină (IOM) recomandă un anumit câş̧ig ponderal la femeia gravidă cu sarcină unifetală în funcție de indicele de masă corporală (IMC) de la debutul sarcinii. Astfel, pentru un IMC normal la momentul concepţiei $\left(18,5-24,9 \mathrm{~kg} / \mathrm{m}^{2}\right)$, se recomandă un câştig ponderal de 11,5-16 kg, câștig la care complicaţiile pe timpul sarcinii sunt minime (3). În schimb, la gravidele cu un IMC mai mare, câştigul ponderal trebuie sa fie invers proporțional cu IMC-ul. Astfel pentru gravidele cu IMC $<18,5 \mathrm{~kg} / \mathrm{m}^{2}$, câștigul ponderal recomandat este de $12,5-18 \mathrm{~kg}$, pentru cele cu IMC $=25-29,9 \mathrm{~kg} / \mathrm{m}^{2}$, supraponderale, se recomandă un câştig ponderal de $7-11,5 \mathrm{~kg}$, iar pentru cele obeze cu IMC $>30 \mathrm{~kg} / \mathrm{m}^{2}$, câștigul ponderal ar trebui să fie de $5-9 \mathrm{~kg}$. La gravida cu sarcină multiplă şi IMC normal, câştigul ponderal ar trebui să fie de $17-25 \mathrm{~kg}$, la supraponderale $14-23 \mathrm{~kg}$, iar la cele obeze 
11-19 kg (4). O metaanaliză, care a analizat complicaţiile secundare câştigului ponderal excesiv al gravidei asupra sarcinii şi nou-născutului, a evidenţiat că acesta se asociază cu nou-născuți LGA, hipertensiune sau preeclampsie, demonstrând că, dacă acesta are loc în primele 20 de săptămâni gestaţionale, crește riscul de diabet zaharat gestaţional (5).

\section{FACTORII DE RISC ÎN OBEZITATEA MATERNĂ}

Este bine cunoscută asocierea dintre câştigul ponderal în sarcină și morbiditatea maternă. În acest sens, un studiu ce a urmărit peste 2,4 milioane gravide în SUA a concluzionat că $31 \%$ dintre gravide au avut un câştig ponderal optim conform IOM, pe când aproape jumătate din gravide au avut exces ponderal (6). Câştigul ponderal în sarcină depinde de factori etnici, sociali şi de paritate. Astfel, gravidele fără studii superioare, cele separate de partener, cele cu situaţie financiară precară şi multiparele au de obicei un câştig ponderal deficitar in sarcină (7). Studiul lui Zhang şi colab. a evidențiat că factorii sociali și economici au un impact major asupra prognosticului fetal la naştere şi asupra celui postpartum, dovedind că nou-născuții din mame cu educație precară, nivel economic scăzut, fumătoare sau cu status nutrițional inadecvat prezintă mai frecvent evoluție nefavorabilă (8). În schimb într-un studiu realizat de Neves şi colab., educaţia are un rol important, 58,3\% dintre gravidele cu 8 ani de studiu fiind obeze, în timp ce, în cazul celor cu 12 ani de studii, doar 36,6\% au fost obeze (9). De asemenea, emeza gravidică în primul trimestru se asociază mai frecvent cu un deficit ponderal în cursul sarcinii, fără un câștig ponderal optim până la sfârșitul sarcinii, după cum arată studiul lui Meinich (10). Câştigul ponderal în primul trimestru este esenţial pentru bunăstarea fetală şi greutatea acestuia, considerându-se că greutatea la naştere depinde de câştigul ponderal în prima jumătate a gestaţiei (11). Karachaliou şi colab. însă consideră că este mai importantă greutatea acumulată de gravidă în trimestrele 2 şi 3 de sarcină (12). Se pare că emeza gravidică din primul trimestru se poate asocia, pe de altă parte, și cu excesul ponderal gestaţional (13).

Vârsta este un alt factor decisiv pentru câștigul ponderal gestațional. Astfel, Stuebe şi colab. au demonstrat că gravidele cu vârsta de peste 35 ani au avut și ele un câştig ponderal mai scăzut decât cele din grupa de vârstă 20-35 ani (13).

Diferențele etnice pot influența la rândul lor evoluția sarcinii și prognosticul fetal. Madzia şi colab. au observat că rasa neagră prezintă un risc mai mare pentru câştig ponderal gestaţional scăzut şi naş- tere prematură comparativ cu rasa albă (14). Similar, Fontaine şi colab. au concluzionat că gravidele din rasa neagră au avut un câştig ponderal diminuat în toate trimestrele versus rasa albă, cu excepția gravidelor subponderale la începutul sarcinii (15). Kinnunen şi colab. au observat un câş̧ig ponderal mai mare la 28 săptămâni de gestație la gravidele est-europene versus cele din vestul Europei, cât şi faţă de cele din Orientul mijlociu. Autorii au arătat, de asemenea, că gravidele caucaziene au avut cele mai mari depozite de grăsime (16).

Paritatea este corelată cu IMC-ul preconcepţional, după cum a demonstrat și studiul lui Paulino şi colab. în cazul gravidelor multipare, obezitatea având o incidenţă dublă față de primipare, totuşi câş̧tigul ponderal gestaţional nefiind asociat cu numărul de naşteri ale gravidei (17). Rezultate similare au fost evidențiate şi în metaanaliza lui Hill şi colab., care a concluzionat că multiparele prezintă un IMC crescut preconcepţional comparativ cu nuliparele (18). Studiul lui Fraser şi colab. a avut ca scop urmărirea excesului ponderal restant prin evaluarea valorilor IMC, a circumferinţei taliei şi a tensiunii arteriale la femei după 16 ani de la naştere. Autorii au demonstrat că femeile cu un câştig ponderal gestaţional mai mic decât recomandările IOM au avut un IMC şi o circumferinţă a taliei mai mică decât cele cu exces ponderal în sarcină (19).

Diabetul zaharat gestaţional, definit ca diabet zaharat diagnosticat în trimestrul 2 sau 3 de sarcină la o gravidă fără antecedente, reprezintă una dintre principalele patologii gestaționale ce se asociază cu un câştig ponderal gestaţional excesiv (20). Un studiu genetic efectuat de Zhang şi colab. a identificat mai multe gene care cresc riscul diabetului zaharat gestaţional, printre care 6 sunt legate de secreţia de insulină şi una de insulino-rezistență (21).

Fumatul în sarcină se asociază cu un câştig ponderal scăzut, demonstrându-se că gravidele care renunţă la fumat în timpul sarcinii sau cu puţin timp înainte de concepţie prezintă un câştig mai mare ponderal în comparație cu cele care continuă să fumeze (22). Mai mult, feţii din mame fumătoare vor avea greutate mai mică la naştere, precum și dimensiuni mai mici ale capului şi lungimii femurului începând cu al doilea trimestru de sarcină (23). Astfel, s-a observat că pentru o gravidă multipară fumătoare este necesar un câștig ponderal între 16 şi 19 kg versus $5-9$ kg în cazul uneia multipare nefumătoare pentru a se menţine un risc similar de SGA, fapt care, evident, va promova excesul ponderal restant după naştere (4). Cu toate acestea, Poon şi colab. au arătat că, independent de aportul caloric în sarcină, gravidele fumătoare au născut mai frecvent feţi SGA, concluzionând că nu 
doar câştigul ponderal în sarcină şi aportul caloric se corelează cu greutatea fătului la naştere (24).

Exceptând factorii menţionaţi anterior, nu este de neglijat nici impactul major al susceptibilității genetice, punându-se în evidență că există trei perioade principale ce influenţează evoluţia fetală, și anume periconcepţională, intrauterină şi postnatală (25). În plus, Yajnik şi colab. consideră că gametogeneza, embriogeneza şi momentul formării placentei reprezintă etape esenţiale de prevenţie în prevenirea riscurilor produsului de concepţie (26).

După Lagadec şi colab., factorii favorabili ce influenţează calitatea vieţii gravidei, cu efect asupra stării de bine a mamei şi fătului sunt nivelul socioeconomic ridicat, primiparitatea, exerciţiile fizice în sarcină, în timp ce obezitatea, hiperemeza gravidică, fertilizarea in vitro, complicaţiile apărute înainte sau pe parcursul sarcinii reprezintă factori cu efect negativ (27).

\section{IMPACTUL STATUSULUI NUTRIȚIONAL AL FEMEII GRAVIDE ASUPRA NOU-NĂSCUTULUI}

Mediul intrauterin deține un rol esenţial în dezvoltarea optimă a fătului, având efect asupra structurilor şi funcţiilor organelor produsului de concepție, considerându-se în acest moment că bolile adultului îşi au originea în perioada perinatală (28). Este bine cunoscut faptul că nutriția gravidei are impact asupra fătului. Astfel, studiul lui Williams şi colab. a demonstrat că IMC-ul mamei, câştigul ponderal gestațional al acesteia şi stilul de viaţă reprezintă factori de risc pentru obezitatea produsului de concepţie, fie imediat postpartum prin macrosomie, fie prin apariţia obezitaţii infantile şi creşterea incidenţei diabetului zaharat (29). Prin urmare, excesul ponderal gestațional deține un rol decisiv în apariţia obezităţii şi bolilor metabolice la copil, de aici rezultând importanţa majoră a unei diete echilibrate pe perioada sarcinii pentru a favoriza un câștig ponderal optim cu efect pozitiv asupra bunăstării fetale, care să prevină riscul metabolic al produsului de concepţie. Atât feţii SGA, cât şi cei LGA asociază rate de morbiditate crescute, cu creșterea riscului de diabet zaharat tip 2 la cei SGA și a celui de supraponderabilitate sau obezitate la cei LGA (30). Godfrey şi colab. au concluzionat că

Conflict of interest: none declared

Financial support: none declared

\section{BIBLIOGRAFIE}

1. Godfrey KM, Reynolds RM, Prescott SL, Nyirenda M, Jaddoe VWV, Eriksson JG, et al. Influence of maternal obesity on the long-term health of offspring. Lancet Diabetes Endocrinol. 2017 Jan;5(1):53-64. obezitatea maternă se corelează cu apariţia bolii cardiovasculare şi a atacului vascular cerebral în perioada de adult cu astmul bronșic în perioada copilăriei (1). Pe de altă parte, s-a observat că pierderea ponderală preconcepțională la femeile obeze poate scădea riscul de obezitate (31).

Studiul lui Mina şi colab. a demonstrat că nivelurile de cortizol la copiii ce provin din mame obeze, cu un nivel suboptim de HDLc, sunt mai mari (32). Tulburările neuro-psihice și de inserție socială nu sunt de neglijat la pacienții obezi. Astfel, un studiu care a urmărit efectele neuropsihice ale copiilor ce provin din mame cu obezitate a observat că acești copii sunt mai predispuși pentru a dezvolta un comportament agresiv, tulburări ale somnului şi semne de tulburare de deficit de atenţie şi de hiperactivitate (ADHD) (33).

O altă ipoteză demnă de menționat ar fi implicația obezității materne în alergiile copilului. Astfel, într-o metaanaliză ce a inclus 14 studii, Forno şi colab. au constatat prezenţa astmului şi a wheezing-ului ca fiind mai frecvente la copiii proveniți din mame obeze (34). În mod similar, Chen şi colab. au corelat alergiile la copii cu IMC-ul mamei şi câştigul ponderal gestaţional, evidenţiind prezenţa mai frecventă a wheezing-ului, astmului, rinitei alergice sau a eczemei drept consecinţă a unui câştig ponderal excesiv în sarcină, fără a putea însă corela IMC-ul pregestaţional al mamei cu prezenţa alergiilor (35). Druker şi colab. au efectuat, de asemenea, un studiu pe un lot reprezentativ de gravide și copii cu dermatită atopică şi au observat că aceasta se asociază cu câștigul ponderal gestaţional, fără a fi influenţată de IMC-ul pregestaţional (36). Pe de altă parte, studiul lui Harpsoe şi colab. nu a găsit nicio legătură între câş̧igul ponderal în sarcină si dermatita atopică (37).

\section{CONCLUZII}

Câștigul ponderal gestațional deține un rol major în apariția diferitelor patologii din perioada copilăriei. Astfel, greutatea maternă poate avea un rol dihotom, asigurând starea de bine a fătului și nou-născutului, sau, dimpotrivă, un status nutrițional matern inadecvat va avea un impact negativ asupra dezvoltării intrauterine a produsului de concepție, dar și ulterior, în ceea ce privește complicațiile pe termen lung și scurt ale copilului.
2. Rooney BL, Schauberger CW. Excess pregnancy weight gain and long-term obesity: one decade later. Obstet Gynecol. 2002 Aug;100(2):245-52. 
3. Most J, Dervis S, Haman F, Adamo KB, Redman LM. Energy Intake Requirements in Pregnancy. Nutrients. 2019 Aug 6;11(8).

4. Institute of Medicine (US) and National Research Council (US) Committee to Reexamine IOM Pregnancy Weight Guidelines. Weight Gain During Pregnancy: Reexamining the Guidelines. Rasmussen KM, Yaktine AL, editors. Washington (DC): National Academies Press (US); 2009.

5. Santos S, Voerman E, Amiano P, Barros H, Beilin LJ, Bergström A, et al. Impact of maternal body mass index and gestational weight gain on pregnancy complications: an individual participant data meta-analysis of European, North American and Australian cohorts. BJOG. 2019 Jul;126(8):984-95.

6. Leonard SA, Abrams B, Main EK, Lyell DJ, Carmichael SL. Weight gain during pregnancy and the risk of severe maternal morbidity by prepregnancy BMI. Am J Clin Nutr. 2020 Apr 1;111(4):845-53.

7. Hickey CA. Sociocultural and behavioral influences on weight gain during pregnancy. Am J Clin Nutr. 2000 May;71(5 Suppl):1364S-70S.

8. Zhang P, Wu J, Xun N. Role of Maternal Nutrition in the Health Outcomes of Mothers and Their Children: A Retrospective Analysis. Med Sci Monit. 2019 Jun 14;25:4430-7.

9. Neves AG, Kasawara KT, Godoy-Miranda AC, Oshika FH, Chaim EA, Surita FG. Early menarche and teenager pregnancy as risk factors for morbid obesity among reproductive-age women: A case-control study. Clinics (Sao Paulo). 2017 Oct; 72(9):547-53.

10. Meinich T, Trovik J. Early maternal weight gain as a risk factor for SGA in pregnancies with hyperemesis gravidarum: a 15-year hospital cohort study. BMC Pregnancy Childbirth. 2020 Apr 28;20(1):255.

11. Retnakaran R, Wen SW, Tan H, Zhou S, Ye C, Shen M, et al. Association of Timing of Weight Gain in Pregnancy With Infant Birth Weight. JAMA Pediatr. 2018 Feb 1;172(2):136-42.

12. Karachaliou M, Georgiou V, Roumeliotaki T, Chalkiadaki G, Daraki V, Koinaki S, et al. Association of trimester-specific gestational weight gain with fetal growth, offspring obesity, and cardiometabolic traits in early childhood. Am J Obstet Gynecol. 2015 Apr;212(4):502.e1-14.

13. Stuebe AM, Oken E, Gillman MW. Associations of diet and physical activity during pregnancy with risk for excessive gestational weight gain. Am J Obstet Gynecol. 2009 Jul;201(1):58.e1-8.

14. Madzia J, McKinney D, Kelly E, DeFranco E. Influence of Gestational Weight Gain on the Risk of Preterm Birth for Underweight Women Living in Food Deserts. Am J Perinatol. 2020 Mar 4.

15. Fontaine PL, Hellerstedt WL, Dayman CE, Wall MM, Sherwood NE. Evaluating body mass index-specific trimester weight gain recommendations: differences between black and white women. J Midwifery Womens Health. 2012 Aug;57(4):327-35.

16. Kinnunen TI, Waage CW, Sommer C, Sletner L, Raitanen J, Jenum AK. Ethnic Differences in Gestational Weight Gain: A PopulationBased Cohort Study in Norway. Matern Child Health J. 2016 Jul;20(7):1485-96.

17. Paulino DS de M, Surita FG, Peres GB, do Nascimento SL, Morais SS. Association between parity, pre-pregnancy body mass index and gestational weight gain. J Matern Fetal Neonatal Med. 2016 Mar;29(6):880-4.

18. Hill B, Bergmeier H, McPhie S, Fuller-Tyszkiewicz M, Teede H, Forster $\mathrm{D}$, et al. Is parity a risk factor for excessive weight gain during pregnancy and postpartum weight retention? A systematic review and meta-analysis. Obes Rev. $2017 \mathrm{Jul} ; 18(7): 755-64$.

19. Fraser A, Tilling K, Macdonald-Wallis C, Hughes R, Sattar N, Nelson $\mathrm{SM}$, et al. Associations of gestational weight gain with maternal body mass index, waist circumference, and blood pressure measured $16 \mathrm{y}$ after pregnancy: the Avon Longitudinal Study of Parents and Children (ALSPAC). Am J Clin Nutr. 2011 Jun;93(6):1285-92.

20. American Diabetes Association. 2. Classification and Diagnosis of Diabetes: Standards of Medical Care in Diabetes-2019. Diabetes Care. 2019 Jan;42(Suppl 1):S13-28.
21. Zhang C, Bao W, Rong Y, Yang H, Bowers K, Yeung E, et al. Genetic variants and the risk of gestational diabetes mellitus: a systematic review. Hum Reprod Update. 2013 Aug;19(4):376-90.

22. Rockhill KM, England LJ, Tong VT, Sharma AJ. Biochemically confirmed smoking cessation and gestational weight gain. Birth. 2019 Jun; 46(2):326-34.

23. Abraham M, Alramadhan S, Iniguez C, Duijts L, Jaddoe VWV, Den Dekker HT, et al. A systematic review of maternal smoking during pregnancy and fetal measurements with meta-analysis. PLoS One. 2017;12(2):e0170946.

24. Poon AK, Yeung E, Boghossian N, Albert PS, Zhang C. Maternal Dietary Patterns during Third Trimester in Association with Birthweight Characteristics and Early Infant Growth. Scientifica (Cairo). 2013;2013:786409.

25. Franzago M, Fraticelli F, Stuppia L, Vitacolonna E. Nutrigenetics, epigenetics and gestational diabetes: consequences in mother and child. Epigenetics. 2019 Mar;14(3):215-35.

26. Yajnik CS. Transmission of obesity-adiposity and related disorders from the mother to the baby. Ann Nutr Metab. 2014;64 Suppl 1:8-17.

27. Lagadec N, Steinecker M, Kapassi A, Magnier AM, Chastang J, Robert $S$, et al. Factors influencing the quality of life of pregnant women: a systematic review. BMC Pregnancy Childbirth. 2018 Nov 23;18(1):455.

28. Simeoni U, Armengaud JB, Siddeek B, Tolsa JF. Perinatal Origins of Adult Disease. Neonatology. 2018;113(4):393-9.

29. Williams CB, Mackenzie KC, Gahagan S. The effect of maternal obesity on the offspring. Clin Obstet Gynecol. 2014 Sep; 57(3):508-15.

30. Cnattingius S, Villamor E, Lagerros YT, Wikström A-K, Granath F. High birth weight and obesity - a vicious circle across generations. Int J Obes (Lond). 2012 Oct;36(10):1320-4.

31. Smith J, Cianflone K, Biron S, Hould FS, Lebel S, Marceau S, et al. Effects of maternal surgical weight loss in mothers on intergenerational transmission of obesity. J Clin Endocrinol Metab. 2009 Nov;94(11):4275-83.

32. Mina TH, Lahti M, Drake AJ, Forbes S, Denison FC, Räikkönen K, et al. Maternal lipids in pregnancy are associated with increased offspring cortisol reactivity in childhood. Psychoneuroendocrinology. 2017 Sep;83:79-83.

33. Mina TH, Lahti M, Drake AJ, Räikkönen K, Minnis H, Denison FC, et al. Prenatal exposure to very severe maternal obesity is associated with adverse neuropsychiatric outcomes in children. Psychol Med. 2017 Jan;47(2):353-62.

34. Forno E, Young OM, Kumar R, Simhan H, Celedón JC. Maternal obesity in pregnancy, gestational weight gain, and risk of childhood asthma. Pediatrics. 2014 Aug;134(2):e535-546.

35. Chen Y, Zhu J, Lyu J, Xia Y, Ying Y, Hu Y, et al. Association of Maternal Prepregnancy Weight and Gestational Weight Gain With Children's Allergic Diseases. JAMA Netw Open. 2020 Sep 1;3(9):e2015643.

36. Drucker AM, Pope EI, Field AE, Qureshi AA, Dumas O, Camargo CA. Association Between Maternal Pre-Pregnancy Body Mass Index, Gestational Weight Gain, and Offspring Atopic Dermatitis: A Prospective Cohort Study. J Allergy Clin Immunol Pract. 2019 Jan;7(1):96-102.e2.

37. Harpsøe MC, Basit S, Bager P, Wohlfahrt J, Benn CS, Nøhr EA, et al. Maternal obesity, gestational weight gain, and risk of asthma and atopic disease in offspring: a study within the Danish National Birth Cohort. J Allergy Clin Immunol. 2013 Apr;131(4):1033-40. 